\title{
The Effects of FDI on Domestic Investments in Western Balkans
}

\author{
Bilal Sucubasi ${ }^{1}$, Borce Trenovski ${ }^{2,}$, Berkan Imeri $^{3}$, and Gunter Merdzan ${ }^{2}$ \\ ${ }^{1}$ Chief Executive Officer of Halkbank AD Skopje, Ss. Cyril \& Methodius 54, Skopje 1000, Republic \\ of North Macedonia \\ ${ }^{2}$ Ss. Cyril and Methodius University in Skopje, Faculty of Economics - Skopje, Blvd. Goce Delchev \\ 9V, 1000 Skopje, Republic of North Macedonia \\ ${ }^{3}$ Director of Financial Management, Accounting and Credit Analysis Division of Halkbank AD Skopje, \\ Ss. Cyril \& Methodius 54, Skopje 1000, Republic of North Macedonia
}

\begin{abstract}
.
Research background: In order to contribute to economic growth, inward foreign direct investments (FDI) need to meet certain economic and social criteria. Besides the contribution to the level of education, technological level, financial development, tax system, trade and investment policies, and market size, FDI should also encourage domestic investments (crowding ineffect).

Purpose of the article: This paper examines the importance and effects of the inward and outward direct investments, gross savings as well as real growth on domestic investments in the case of Western Balkan countries (North Macedonia, Serbia, Albania, Kosovo, Montenegro, and Bosnia \& Herzegovina). Thus, the logic behind this research is to determine whether and in which direction are aimed effects of FDI.

Methods: The relation between FDI and domestic investments has been analyzed by employing panel data approach with and without constrains on cross-sections. The study is based on a panel data of six countries for the period between 2007-2018, (i.e., in total, we have 66 observations).

Findings \& Value added: The general conclusion from this analysis confirm that inward foreign direct investments in the Western Balkans, as well as real economic growth both significantly and positively affect the domestic investments.
\end{abstract}

Keywords: foreign direct investments; domestic investments; crowding ineffect; fixed effects model

JEL Classification: $F 21 ; F 23 ; F 43$

\section{Introduction}

One of the biggest challenges in the developing countries is the insufficient capital accumulation that should provide the necessary investment for economic growth. If the country has a shortage of savings, it tries to provide the required amount of capital through

\footnotetext{
* Corresponding author: Borce.Trenovski@eccf.ukim.edu.mk
} 
foreign savings. The foreign savings are provided by foreign loans, borrowings or foreign capital inflows. Accordingly, the developing countries are obligated to enhance sustainable economic growth, to increase the international competitiveness and to implement policies towards foreign direct investment (FDI). The increased capital accumulation after the Second World War, increased the interest in new investment areas. Hence, there was a significant increase of the capital investment in the developing countries which were experiencing severe balance of payments difficulties. The Organization for Economic Co-operation and Development (OECD), defines FDI as a long-lasting relationship between the direct investment and the enterprise, i.e., conducting long-term control on the production, distribution, or other economic activities by the companies that have a subsidiary in other countries. These investments are introduced by multinational enterprises (MNEs) and by increasing fixed capital, technology, managerial knowledge, etc. are contributing to economic growth.

In the process of economic developing of the countries, FDI increases the opportunity for economic growth, improves the balance of payments, increases the export by improving the trade process and by implementing new knowledge environment, creates more skilled labour force and increases the employment rate. However, in order to contribute to the economic growth, some economic or social criteria should be satisfied. Beside the education, technology usage level, financial development, tax system, trade and investment policies and market size, the FDI should have an impact on the domestic investment in order to cause the "crowding in" effect and to cause a multiplied economic growth. In case of insufficient capital accumulation, FDI can increase the production capacity and employment. Moreover, FDI can increase the technology usage level and can introduce modern technologies, which will additionally increase the international competitiveness, resulting with reduced imports. On the other hand, if the increasing rate of the total investment is lower than the increasing rate of the FDI, the "crowding out" effect occurs. In this case, the adverse effects of FDI on domestic investment overcomes, meaning that FDI substitute the domestic investment.

This research paper analyzes the impact of FDI on domestic investments in Western Balkans countries. The structure of this paper is as follows. The first part provides a definition of FDI and provides historical overview of the worldwide FDI with particular reference to developing countries. The second part will provide relevant literature review regarding the effects of FDI on domestic investment. The development and distribution of total FDI and by activities in the mentioned countries, are also discussed in the previous section. According to the main purpose of this research, the empirical evidence is crucial. Therefore, in the last part, an econometric analysis is used in order to test the effects from the FDI on domestic investments.

\subsection{Foreign Direct Investments}

In a period of three centuries before World War I, the capital was moving to the areas with higher concentration of natural resources and in areas with lower concentration of population. In the first half of the 19. century, the beginnings of the foreign investment were mainly in England's colonies, due to the increased needs of raw materials, metals and oil extraction. The Industrial Revolution in the second half of the 19. century, forced large corporations to direct the capital from Western industrialized countries with high capital concentrations, to new investment areas with higher potentials for profits. These investments were introduced as a type of FDI's. New investment areas were the colonies and independent underdeveloped countries wherefrom the European industry was extracting the raw materials, natural resources and low-cost labour. During the XIX century the capital was owned by the Western European countries, and after the World War I, the United States of America (USA) took over the domination of FDI. Compared with the previous period, after 1920s, there was a 
huge increase in FDI. In this period, right before the Great Depression of 1929-1933 (19211929), the movement of capital was from the industrialized to the underdeveloped countries. These investments were introduced as a portfolio investment. However, the Great Depression became turning point for FDI.

During the World War II, the dominance of England and USA regarding the FDI resulted with a concentration of export sectors in the central countries, and agriculture and mining sectors in the peripheral countries. In the postwar period, there was an increase of FDI. According to IMF, in 1960 in the developing countries FDI were 2 billion dollars, while in 1982 they increased to 10 billion dollars. Subsequently, the war caused bad consequences in Europe and the interest in American investment significantly increased. These investments were mostly from industry and infrastructure sectors. However, during the 1970s and 1980s, the investments began to decline. Due to the increasing production costs in Europe, and the value of European currencies against the US dollar, US began to look for new investment areas. During this period, due to the reduced attractiveness of Europe, developing countries attracted a lot of attention regarding FDI.

After 1980s national economies began to open up towards the world markets, they had capital account liberalization, and started the processes of privatization and deregulation. This processes caused the increasing of global FDI and the developing countries turned into developed manufacturing centers. In the 1900s was noticed a significant impact of the increased FDI on the economic growth in Asian countries. However, after the debt crisis in Southeast Asia in 1997, the share of developing countries in total FDI have gradually declined. In 1997, 43\% of total 485 billion dollars FDI were concentrated in the developing countries. In 2000 year, this share was reduced to $18 \%$ as a consequence of the Asian crisis, Russian crisis and other global crisis. As a result of the institutional and legal reforms, and the liberalization trends, the investment in these countries was increasing again. In 2002, $33 \%$ of the total 589 billion dollars of FDI were concentrated in the developing countries. Furthermore in 2009 during the Economic crisis $46 \%$ of the total FDI were in the developing countries. In 2012 and 2013 this share was increasing and reach 58\%, surpassing the share of FDI in the developed countries. Accordingly, developing countries attract more than half of FDI worldwide. Nowadays, MNEs with its trade activities plays a major role in the global economy. The World Trade Organization (WTO), the International Monetary Fund (IMF) and the World Bank (WB), were pursuing liberalization policies since the 1980s along with the globalization process, and have a major impact on the MNC. According to the United Nations Conference on Trade and Development (UNCTAD), 37.000 MNCs and 170.000 foreign subsidiaries were active in the early 1990s, and in 2007 these numbers increased to 79,000 and 790,000 , respectively; with a total $\$ 15$ trillion of FDI and a total sale of $\$ 31$ trillion, they exceeded $10 \%$ of the world's gross domestic product (GDP). The share of G20 countries in the total FDI worldwide decreased from $76 \%$ in 1980 , to $65 \%$ in 2000 and $54 \%$ in $2013 .^{\dagger}$

\subsubsection{The Role of FDI in the Economies of the Western Balkan Countries}

The Western Balkan (WB) countries, who were late to integrate with Europe and the global economy, have also embarked on a FDI-led journey to enhance exports and growth performance. These six countries, Albania, Bosnia and Herzegovina, Kosovo, FYR Macedonia, Montenegro and Serbia, navigated a tumultuous decade of civil war, ethnic struggle and financial crises before engaging in integration. With a late start in transition, most FDI inflows to the WB region took place in the last decade reflecting significant recent policy efforts geared to court foreign investors.

\footnotetext{
${ }^{\dagger}$ For more details see: https://unctad.org/en/Pages/statistics.aspx
} 


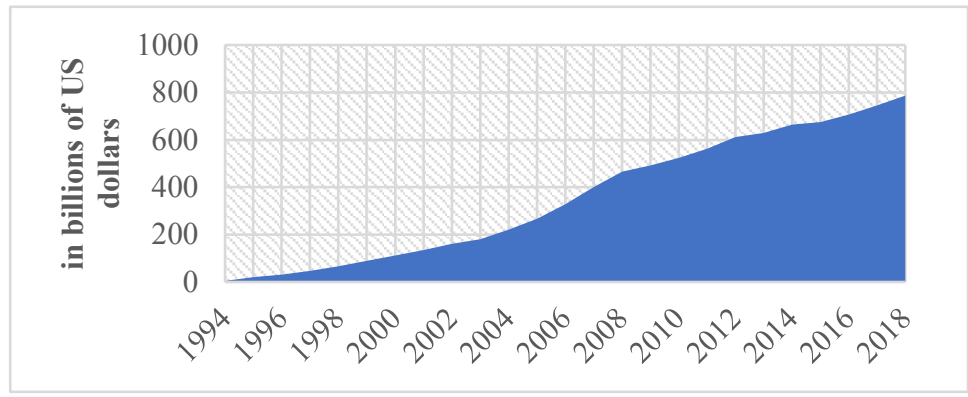

Fig. 1. Cumulative FDI inflows in the New Member States. Source: UNCTAD and WB.

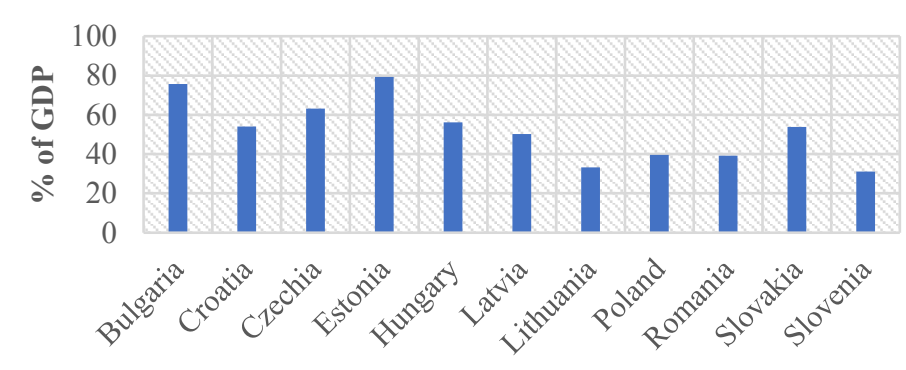

Fig. 2. FDI stock in the New Member States. Source: UNCTAD and WB.

The Western Balkans countries took into account the strong role of FDI in the export-led growth in Eastern European countries that are now part of the European Union (EU). These eleven countries, Bulgaria, Croatia, the Czech Republic, Estonia, Hungary, Latvia, Lithuania, Poland, Romania, Slovakia and Slovenia, which became EU members in 2004 or after, also known as the "New Member States", by the end of 2016 attracted a cumulative total gross FDI of nearly $\$ 700$ billion (Bijsterbosch \& Kolasa, 2010). The FDI inflows in these countries had a particularly upward trend after the EU membership. Compared to other upper-middle income countries, the stock of FDI and both as a percentage of GDP and per capita, are significantly higher. FDI in these countries has also contributed significantly to exports, employment, productivity and growth, with variations between countries.

Serbia and Montenegro have already started negotiations with EU, while North Macedonia and Albania obtained permission for starting the negotiations on Mart 24, 2020. This decision is made according the strategy for Western Balkan, which was announced in 2003. In 2003 at the Thessaloniki Summit was announced that the Western Balkan countries are part of Europe and that if they meet the Copenhagen criteria, they will gradually integrate with the EU. 


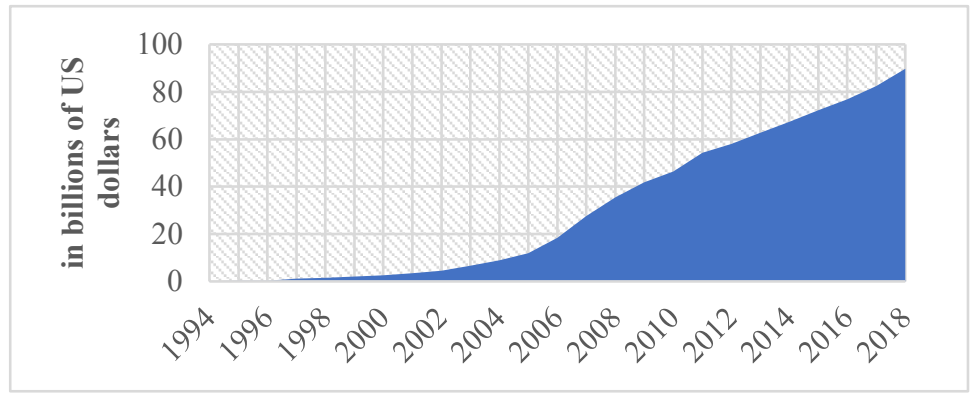

Fig. 3. Cumulative FDI inflows in the Western Balkan Countries. Source: UNCTAD and WB.

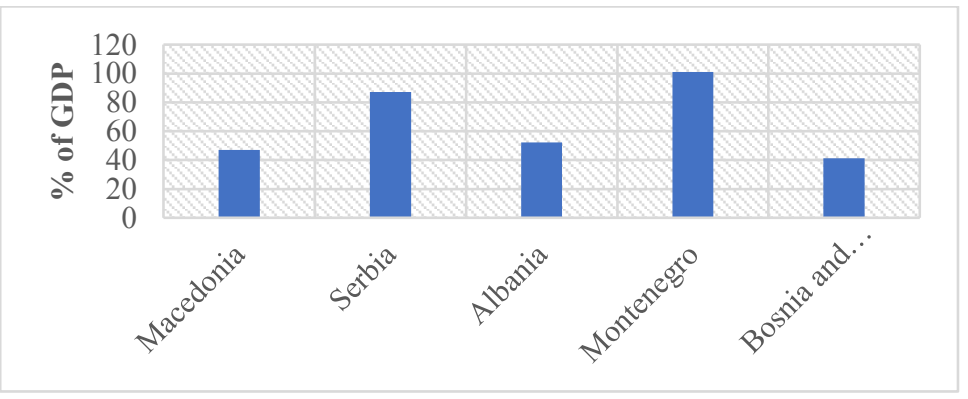

Fig. 4. FDI stock in the Western Balkan Countries. Source: UNCTAD and WB.

However, there are still major uncertainties and problems with Kosovo and Bosnia and Herzegovina, and with other Western Balkan countries. Eventually, by reducing this uncertain aspects of the countries in the region regarding the EU membership, they could gain the same benefits regarding the FDI, exports, employment, productivity and growth (Jirasavetakul \& Rahman, 2018). From the graphs no. 1 and 2 it is shown that during 19942018 the new EU member states attracted a cumulative total gross FDI of almost $\$ 800$ billion, while the Western Balkans countries about $\$ 90$ billion.

\subsection{Literature Review}

The overall benefits of FDI on the economy in the developing countries, have an enormous significance. The biggest benefit of foreign investment is considered the positive impact on economic growth. In order to have a positive impact on the economic growth, FDI should not have a depressing effect on domestic investment. From this aspect, the effects of crowding-out and crowding-in of FDI on domestic investment are of great importance. If the effect of crowding out prevails, then the growth rate of domestic investment will lag behind the growth rate of FDI and FDI will have a substitutive effect on domestic investment. In this situation, the domestic investment will be replaced with foreign investment. Otherwise, if the crowding in effect prevails, then the growth rate of domestic investment will be higher than the growth rate of foreign investment and a complementary relation between these investments will occur. Hence, foreign investments are going to play an important role in the development of domestic investments (De Mello, 1999).

Compared to developed countries, the market capacity in the developing countries is insufficient and the income per capita is low. Additionally, increased investment, production and exports depends on the imported goods and technologies. The increased interest in production and export for ensuring long-term growth was gradually increasing the need for FDI. The effects of FDI in different countries vary on the market size, the country's openness 
rate and investment structure. In addition, because FDI is much more stable than any other type of foreign investment during financial crises, the developing countries use them as an effective resource for external financing. Also, FDI with its beneficial effects on other investors has become a significant stimulus for increasing potential investment.

Countries that aim to attract FDI in order to ensure economic growth, and countries that consider it as an effective source of external financing, are transferring advanced technology to the high-tech sector in order to make the human factor more qualified. As a consequence, production and exports growth is noticed. Taking into account such positive "spillover" of FDI on the national economy, FDI can increase productivity, i.e. contribute to economic growth.

Numerous studies confirm the positive impact of FDI on economic growth. For example, a study Borensztein et al. (1998), which included data for 69 developed countries, suggests that a $1 \%$ increase of FDI share in GDP, increases GDP per capita by $0.8 \%$. The same type of effect was proved by another survey by Kumar and Pradhan (2002). However, a study by Kogut and Singh (1988), which covers 73 countries, found that the impact of FDI on economic growth is minor or non-existent.

In order to attract FDI, the country needs to show economic stability and favorable conditions for economic activities. Therefore, the claim that economic growth has a positive effect on FDI is also accurate. However, another source of economic growth is domestic investment. Domestic investment is also one of the most important factors in Keynes' aggregate demand. Hence, according the accelerator theory and the multiplier effect, one unit of growth in investment will accelerate economic growth (Bilgili, Halici-Tuluce, \& Dogan, 2012).

Generally, FDI and domestic investments are mutually complementary. When FDI is directed at sectors with high concentration of domestic investment, the domestic investors increase the capital reserves in order not to be damaged by greater competition in the sector. Consequently, there is a "capital deepening". If FDI is directed to sectors with lower concentration of domestic investment, the domestic investment will be favorably affected by the competition created in these sectors (De Mello, 1999). Due to insufficient accumulation of capital in a country, FDI increases production capacity and employment opportunities. Additionally, with the high technology implementation, they gradually develop all sectors, improve the manufacturing industries and they reduce the import dependency (Borensztein, De Gregorio, \& Lee, 1998). Another study by Bosworth and Collins (1999), offered an analysis for FDI by using data for 58 developing countries between 1978 and 1995. The study claims that 1-dollar growth in FDI caused an approximately 50 cents increase in domestic investment and therefore, FDI is related to the total investment and does not replace domestic investment. Moreover, a study for the US economy by Desai et al. (2005), shows that a $10 \%$ increase in FDI cause a $2.2 \%$ increase in domestic investment. Investors combine different stages of production in several countries in order to reduce production costs.

Cardoso and Dornbusch (1989), suggest that FDI may also increase domestic investments because of the demand addressed to local suppliers and inputs and therefore have a beneficial effect on domestic investment. The study by Markusen and Venables (1999) pays close attention to the relationship between the final goods produced by foreign companies and the raw materials provided by domestic companies. From a theoretical point of view, they prove that if this relationship is strong, FDI positively affects the economic development.

Kim and Seo (2003), claim that the FDI's effects on expansion, overflows and other positive externalities force domestic companies to invest. They can also lead to high-risk industry development which have lack of domestic investment. However, Hejazi and Pauly (2003), claim that the general acceptance that FDI inflows increase the capital accumulation and the FDI outflows reduces it, is wrong. They claim that the benefits that are offered in 
order to attract FDI are more important for understanding the effect of FDI on capital accumulation.

However, there are empirical studies showing that FDI has a "crowding out" effect on domestic investment. This situation occurs when FDI negatively affects the growth and accumulation of knowledge of domestic companies, or causes a decrease of skilled labour and capital in the industries. The study by Agosin and Mayer (2000), analyzes the developing countries in Asia and Latin America, and the rapid liberalization of FDI policies. The study showed that in Asian countries the effect of "crowding-in" prevails, while in Latin- American countries prevails the "crowding-out" effect. The positive effects of FDI on domestic investment are not always guaranteed. Sometimes total investment may grow less than the FDI, or FDI may adversely affect the economic growth. In the national economy, sectors with export potential are open to competition and domestic investors can be the potential competitors, but they still do not have the capacity to compete with large MNCs. FDI is particularly detrimental to small and medium-sized enterprises with long learning periods and high production costs. Also, MNCs have a greater capacity to employ qualified human resources. Based on these externalities, it is possible that FDI will have a negative impact on total investment and economic growth.

In a study by Apergis et al. (2006), 30 countries were analyzed by using cointegration and cause-and-effect analysis. The results show that the bivariate model have a significant, two-way and dynamic relation between FDI and domestic investment. On the other hand the multivariate model, show a two way, bi-directional relation and substitutive effects. FDI are increasing the prices of the factors of production, and because of that the usage of inputs and human resources is decreasing. On the other hand, they increase imports and negatively affect the balance of payments. These situations cause a decline of productivity, a price increase and a decrease in domestic investment. If there are huge differences in technology levels between foreign and domestic investment and if there is not enough highly skilled labour in the domestic labour market, then, foreign investors because of the imperfect competition are crowding out domestic investment. Other studies suggest a positive impact of FDI on domestic investment. These results occur when MNCs are operating in more productive sectors. If we consider all the results, we could conclude that the net effect of FDI on the domestic economy is quite small. On the other hand, a study by Feldstein (1994) is analyzing OECD countries and proves that FDI has a depressing effect on domestic investment. The working paper of Sauramo (2008) examines the relationship between the country's direct foreign investment and domestic investment using data for Finland over the period 19652006, when the domestic investments were low. The relationship is analyzed by using dynamic investment equations based on the macroeconomic framework developed by Feldstein (1994). In the model is used annual data for direct investment outflows, domestic investment, domestic savings and GDP. The result suggests that a dollar invested abroad as a direct investment mean one less dollar available to domestic investment in long term (oneto-one trade-off). Furthermore, Fry (1993), in a study covering 16 developing countries, confirms that FDI reduces total investment. Agosin and Machado (2005), in their study covering 36 developing countries from Asia, Africa and South America, argue that the FDI has positive impact on total domestic investment.

\section{Data and Methodology}

This chapter examines the effects of FDI on domestic investments in the case of the Western Balkan countries. We thus first introduce panel regression using domestic investments as a dependent variable. For the independent variables we use FDI, domestic savings (all variables in terms to the GDP) and the real GDP growth rate. The main objective of this study 
is to examine if the domestic investments, domestic savings and economic growth are dependent on FDI`s.

The analysis is made with annual data for the period 2007-2018 for the previously mentioned Western Balkan countries, using EViews econometric software. The data consists of domestic investments, FDI outflows and inflows and domestic savings as GDP ratios. Meanwhile, the economic growth is shown as a real growth of GDP. More detailed information on the used variables is given in the table below.

Table 1. Description of the variables

\begin{tabular}{|c|c|c|c|}
\hline Variable & $\begin{array}{c}\text { Variable } \\
\text { Short Names }\end{array}$ & Explanation & Source \\
\hline $\begin{array}{l}\text { Domestic } \\
\text { investments / } \\
\text { GDP }\end{array}$ & $\begin{array}{l}\text { domestic_inve } \\
\text { stments }\end{array}$ & $\begin{array}{l}\text { Gross investment contain total } \\
\text { expenditure on buying new fixed } \\
\text { assets in the economy plus net } \\
\text { changes in inventories The variable is } \\
\text { measured in terms of GDP }\end{array}$ & $\begin{array}{l}\text { World Bank National } \\
\text { Accounts Data and } \\
\text { OECD National } \\
\text { Accounts Data Files }\end{array}$ \\
\hline $\begin{array}{l}\text { FDI inflows / } \\
\text { GDP }\end{array}$ & fdi_inflows & $\begin{array}{l}\text { FDI inflow data refer to the inflow of } \\
\text { direct investment in the country. It } \\
\text { contains of newly invested capital, } \\
\text { reinvestment of profits and other types } \\
\text { of capital. The variable is measured in } \\
\text { terms of GDP }\end{array}$ & $\begin{array}{l}\text { World Bank National } \\
\text { Accounts Data and } \\
\text { OECD National } \\
\text { Accounts Data Files }\end{array}$ \\
\hline $\begin{array}{l}\text { FDI outflows } \\
\text { / GDP }\end{array}$ & fdi_outflows & $\begin{array}{l}\text { FDI outflow data refer to the outflow } \\
\text { of direct investment in a foreign } \\
\text { country. It contains of newly invested } \\
\text { capital, reinvestment of profits and } \\
\text { other types of capital. The variable is } \\
\text { measured in terms of GDP }\end{array}$ & $\begin{array}{l}\text { World Bank National } \\
\text { Accounts Data and } \\
\text { OECD National } \\
\text { Accounts Data Files }\end{array}$ \\
\hline $\begin{array}{c}\text { Gross savings } \\
\text { / GDP }\end{array}$ & savings & $\begin{array}{l}\text { Gross saving is calculated as gross } \\
\text { national income minus consumption } \\
\text { plus net transfers. The variable is } \\
\text { measured in terms of GDP }\end{array}$ & $\begin{array}{l}\text { World Bank National } \\
\text { Accounts Data and } \\
\text { OECD National } \\
\text { Accounts Data Files }\end{array}$ \\
\hline $\begin{array}{l}\text { Real Growth } \\
\text { of GDP }\end{array}$ & rgdpg & $\begin{array}{l}\text { The real growth refer to the real GDP. } \\
\text { They are shown as percentages of } \\
\text { growth. }\end{array}$ & $\begin{array}{l}\text { World Bank National } \\
\text { Accounts Data and } \\
\text { OECD National } \\
\text { Accounts Data Files }\end{array}$ \\
\hline
\end{tabular}

Econometrically, the general model we use for estimation when using panel data can be described as (Brooks, 2014):

$$
\gamma_{i t}=\alpha+\beta x_{i t}+u_{i t}
$$

where $\gamma_{i t}$ is a dependent variable, $\alpha$ is the intercept term, $\beta$ is a $\mathrm{k} \times 1$ vector of the parameters of the explanatory variables to be estimated and $\mathrm{x}_{\mathrm{it}}$ is a $1 \times \mathrm{k}$ vector of observations of the explanatory variables, $t=1, \ldots, T ; i=1, \ldots, N$.

The simplest way to analyze panel data is by estimating aggregate regression, which involves estimating one equation for all data, so that the $\gamma$ database is arranged in a single column containing all cross-member observations and time series, and similarly, all observations of each explanatory variable are arranged in single columns in the matrix $\mathrm{x}$. In that case, this equation is estimated in the usual way using the ordinary least squares (MLS) method.

Although this is a really simple way to proceed, and requires an assessment of as few parameters as possible, the procedure has some serious limitations. Most importantly, the 
aggregation of data in this way implicitly assumes that the average values of the variables and the relationships between them are constant over time and across all the cross-members in the sample. We could, of course, estimate individual time series regressions for each member or country, but this would probably be a sub-optimal way to proceed as this approach would not take into account any common structure present in the time series. Alternatively, we could estimate individual cross-regressions for each particular time period, but again this may not be wise if there are some common variations in the series over time (Brooks, 2014).

To solve this problem, we choose between two classes of panel evaluation approaches that can be used in such research: fixed effects models and random effects models. The simplest types of fixed effect models allow the intercept in the regression model to differ between the cross-members, but not overtime, while all estimated slope coefficients are fixed both cross-sectionally and temporally.

The fixed effects model can be estimated using the following equation (Brooks, 2014):

$$
\gamma_{i t}=\alpha+\beta x_{i t}+\mu_{i t}+v_{i t}
$$

where the error member $u_{i t}$, decomposes into an individual specific effect, $\mu_{\mathrm{i}}$, and the "remainder disturbance", $v_{i t}$, which varies with time and terms (including everything that remains unexplained for $\gamma_{i t}$ ). We can count on $\mu_{\mathrm{i}}$ as covering all variables which affect $\gamma_{\text {it }}$ cross-over, but do not differ over time. Specifically, in our model it is estimated by the following equation:

$$
\begin{aligned}
& \text { domestic_investments } 2007-2018 \\
& =\alpha+\beta_{1} \text { fdi_inflows }_{2007-2018} \\
& +\beta_{2} \text { fdi_outflows }_{2007-2018}+\beta_{3} \Delta \text { saving }_{2007-2018} \\
& +\beta_{4} r g d p g_{2007-2018}+\mu+v_{2007-2018}
\end{aligned}
$$

This model could be estimated using dummy variables, which would be termed the last squares dummy variable (LSDV) approach:

$$
\begin{aligned}
& \text { domestic_investments } 2007-2018 \\
& =\beta_{1} \text { fdi_inflows } \text { 2007-2018 }+\beta_{2} \text { fdi_outflows }_{2007-2018} \\
& +\beta_{3} \Delta \text { savings }{ }_{2007-2018}+\beta_{4} \text { rgdpg }_{2007-2018}+\mu_{2} D_{2} \\
& +\mu_{3} D_{3}+\mu_{4} D_{4}+\mu_{5} D_{5}+\mu_{6} D_{6}+v_{2007-2018}
\end{aligned}
$$

Where the first dummy variable is for the first country, where it takes a value of 1 for the first country, and 0 for another countries. The second dummy variable also takes a value of 1 when it comes to second country, and value of 0 for other countries, and so on.

An alternative to the fixed effects model described above is the random effects model. As with the fixed effects model, the random effects approach proposes different intercept terms for each member, and again these intercept terms are constant over time, assuming that the relationships between the explanatory and explained variables are the same both crosswise and temporally.

However, the difference is that according to the random effects model, it is assumed that the intercepts for each cross-member derive from a common intercept $\alpha$ (which is the same for all cross-members, over time), plus a random variable $\epsilon_{i}$, which varies through crossmembers but is constant over time. $\epsilon_{\mathrm{i}}$ measures the random deviation of each entity's intercept term from the "global" intercept term $\alpha$. We can write the panel model with random effects as follows (Brooks, 2014):

$$
\gamma_{i t}=\alpha+\beta x_{i t}+\omega_{i t}, \omega_{i t}=\epsilon_{i}+v_{i t}
$$


where $x_{i t}$, is still a $1 \times \mathrm{k}$ vector of explanatory variables, but unlike fixed effects, there are no dummy variables here to capture heterogeneity (variation) in the cross-sectional dimension. Instead, it happens through members $\epsilon_{i}$. It should be borne in mind that this framework assumes that the new error cross-member $\epsilon_{i}$ has zero mean, is independent of the individual error member $v_{i t}$, has a constant variance $\sigma_{\epsilon}^{2}$, and is independent of the explanatory variables $x_{i t}$. Finally, we run the Hausman test in order to see which of the models in our analysis is recommended and display the results.

\section{Results and Discussion}

In this section, we present the results of the conducted panel regression. First, in order to determine (non)stationarity of the panel or longitudinal data, we tested the integrative characteristics of the used variables using LLC-test (Levin, Lin, and Chu). This test examines the null hypothesis i.e. if variables have a unit root, they are nonstationary. The results of the conducted LLC-test for the integrative characteristics of the used variables in our model, we can conclude that according to the stated test, all variables except gross savings are stationary at level I (0). According to the additional test for integrative characteristics gross savings are considered as nonstationary in that level, but after the first differentiation it becomes stationary I (1). The table 2. shows the results of the integrative characteristics of the used variables.

Then, we evaluate the fixed effects model in order to see what information the "likelihood ratio" gives us from the "Redundant Fixed Effects Tests". The results of this test indicate that in this model it is permissible to impose fixed or random effects on the cross-members, but not on the period. So, it is advisable to work with a model with fixed or random effects, rather than a pooled regression where all data is considered to belong to one entity without paying attention to the different characteristics between entities/cross-member entities. Furthermore, we perform the Hausman test in order to decide which technique should be used in our model.

Table 2. Results of the integrative characteristics of the used variables

\begin{tabular}{ccc}
\hline Variables & Statistics (LLC-test) & p-value od the statistics (LLC-test) \\
\hline domestic_investments & $-5,71082$ & 0,0000 \\
\hline fdi_inflows & $-10,0731$ & 0,0000 \\
\hline fdi_outflows & $-1,71138$ & 0,0435 \\
\hline savings & $-3,74441$ & $0,0001^{\ddagger}$ \\
\hline$\Delta$ savings & $-2,10767$ & 0,0175 \\
\hline rgdpg & $-5,16285$ & 0,0000 \\
\hline
\end{tabular}

Source: Authors' own calculations using EViews.

The p-value of the Chi-square statistic of the Hausman test is $0,42 \%$, i.e. it has a lower value of $5 \%$ or $1 \%$; which means that we can reject the null hypothesis and find that in our case the

\footnotetext{
$\$$ p-the value of LLC statistics for gross savings shows that we can reject the null hypothesis and we are not facing the problem of a unit root. However, other tests we used did not show the same result, i.e. the tests of Im, Pesaran and Shin W-stat, ADF - Fisher Chi-square and PP - Fisher Chi-square, showed that we could not reject the null hypothesis and showed that we need to work with the first differentials from gross savings, $\Delta$ savings.
} 
fixed effects model is recommended. The next step is to estimate the model, i.e. to determine the coefficients of the independent variables by imposing fixed effects on the cross-section in the model, which, proposes different intercepts for all cross-sections. The table and estimated equation below show the results of the estimated model based on equation 3 .

Table 3. Results for the estimated coefficients based on the model with fixed effects

\begin{tabular}{cccc}
\hline Explanatory variables & Coefficient & t-statistics & p-value \\
\hline fdi_inflows & 0,340705 & 2,765860 & 0,0077 \\
\hline fdi_outflows & 0,690117 & 1,464247 & 0,1487 \\
\cline { 1 - 2 }$\Delta$ ssavings & $-0,251512$ & $-1,354474$ & 0,1810 \\
\cline { 1 - 2 } Rgdpg & 0,007375 & 3,810280 & 0,0003 \\
\hline A & 0,208920 & 18,98221 & 0,0000 \\
\hline $\mathbf{R}^{2}$ & 0,718428 & & \\
\cline { 1 - 2 } F-statistics & 15,87592 & & \\
\cline { 1 - 2 } p-value (F-stat) & 0,000000 & & \\
\cline { 1 - 2 } & & &
\end{tabular}

Source: Authors' own calculations using EViews.

domestic_investments $2007-2018$

$$
\begin{aligned}
& =0,21+0,34 \text { fdi_inflows }_{2007-2018} \\
& +0,69 \text { fdi_outflows }_{2007-2018}-0,25 \Delta \text { saving }_{2007-2018} \\
& +0,01 \text { rgdpg }
\end{aligned}
$$

Additionally, although the likelihood ratio showed that we should apply one of the panel regression techniques, we also tested it by imposing certain dummy variables for each of them. This test is a slightly modified version of the Chow test and involves incorporating the restriction that all of the intercept dummy variables have the same parameter. Through the Wald test, we test the null hypothesis that the coefficients of all introduced variables have the same parameter $H_{0}: \mu_{2}=\mu_{3}=\cdots=\mu_{6}$. If we fail to reject the null hypothesis, we can apply the pooled regression. On the other hand, if we reject the null hypothesis, it means that the panel approach should be applied. The p-value of Chi-square-statistics $(48,79111)$ is $0 \%$, i.e. it is less than $5 \%$, and can reject the null hypothesis and accept the alternative hypothesis. Through the Hausman test, we determined that the model with fixed effects is recommended. The results are shown in Table no. 3 .

The coefficient of determination $\mathrm{R}^{2}$ has a value of $71.84 \%$, which indicates that many of the variations in the model are explained by the included variables. The p-value of the Fstatistics of the evaluated model is lower than $5 \%(0 \%)$ and we accept the hypothesis that the explanatory variables have a significant impact on the movement of the dependent variable. Multicollinearity has been tested through the variance-inflation factor (VIF). In order to examine the multicollinearity, we present the FDI inflows as a function of other independent variables. The VIF score of that model is 2.9 ; and it is generally accepted that if VIF is greater than 5 then multicollinearity should be treated as a problem. Also, many experts consider that if the absolute value of the simple correlation coefficients (r) are higher than 0.80 , it is already a sign of strong multicollinearity. In our case, we can say that multicollinearity by both criteria should not be treated as a problem. A Jarque-Bera test has also been performed 
to test whether random errors follow a normal distribution. The p-value of the test statistics is $67.72 \%$, i.e. it has a higher value of $5 \%$; in this case we cannot reject the null hypothesis that the residuals follow a normal distribution.

The results show that the FDI inflows have a significant and positive impact on domestic investment (the p-value of t-statistics is $0.77 \%$ ). Increasing FDI per $1 \%$ increases domestic investment by $0.34 \%$. Also, real economic growth has a positive and significant impact on domestic investment ( $\mathrm{p}$-value of t-statistics is $0.03 \%$ ). Increasing the real GDP growth rate by $1 \%$ increases domestic investment by $0.0074 \%$. While gross savings and direct outflows do not significantly affect the amount of domestic investment. In this case, it might be more appropriate to estimate the model without including gross savings and direct outflows. However, having in mind that in most of the consulted literature in this area, similar variables are used and most often show a significant impact on domestic investment, we decided not to remove them from our model despite their insignificant impact in our case. We also tested the case of disabling the above-mentioned variables and observed issues with the normality of residuals.

\section{Conclusion}

In order to improve the global competitiveness, the MNC began transferring its capital accumulation to the developing countries in 1980. In this context, the national economies, opening up to the outside world, have taken enormous measures to attract foreign investment. As a result, FDI showed an increase globally, and the developing countries took a significant share of the world's FDI. In order to stimulate sustainable economic development and to improve international competitiveness FDI, unlike the portfolio investments, has attracted more attention. FDI in the development process provide the opportunity to finance the economic growth, to improve the balance of payments, to increase export channels by improving trade, to create more skilled labor and to increase employment. On the other hand, FDI have effect on domestic investment in two ways, through a crowding-in effect or a crowding-out effect. These effects depend on the role of FDI in replacing or supplementing domestic investment.

This paper explores the effects of FDI on domestic investments in the Western Balkan countries. In our framework of analysis of a panel data regression, we noticed that FDI inflows have a significant and positive impact on domestic investment. We found that increasing the FDI by $1 \%$ increases domestic investment by $0.34 \%$. Furthermore, the real economic growth has a positive and significant impact on domestic investment. Increasing the real GDP growth rate by $1 \%$ increases domestic investment by $0.0074 \%$. Thus, results indicate that FDI has a more pronounced positive effect on domestic investment compared to GDP growth rates. Gross savings and direct outflows do not significantly affect the amount of domestic investment.

Given the structure of the economies in the Western Balkans, the results of our analysis are in line with some of the channels / conclusions from other studies that highlight the positive effect of FDI on domestic investment and confirm that the total investment and does not replace domestic investment. Part of the logic and explanation of the previous could be found in the role of FDI in - increasing production capacity and employment opportunities; introducing new technology, which gradually develop all sectors, improve the manufacturing industries and reduce the import dependency; because of FDI demand addressed to local suppliers and inputs, which create a beneficial effect on domestic investment.

In order to reduce the eventual risk of an international shock from FDI on domestic investment because of their importance for the countries of the Western Balkans, the structure, productivity and capacity of domestic companies/labor market need to be improved. Also, in order to have a long-lasting effect of FDI on domestic investment, 
governments need to emphasize new policies aimed at common markets, strengthening the links between domestic and foreign companies, and building complementary alliances of interest to both sides.

\section{References}

1. Agosin, M., Machado, R. (2005). Foreign Investment in Developing Countries: Does it Crowd in Domestic Investment? Oxford Development Studies, 33(2), 149162.

2. Agosin, M., Mayer, R. (2000). Foreign Investment in Developing Countries, Does It Crowd in Domestic Investment? Oxford Development Studies, 33(2), 149-162.

3. Apergis, N., Katrakilidis, C., Tabakis, N. (2006). Dynamic Linkages between FDI Inflows and Domestic Investment: A Panel Cointegration Approach. Atlantic Economic Journal, 34(4), 385-394.

4. Bijsterbosch, M., Kolasa, M. (2010). FDI and Productivity Convergence in Central and Eastern Europe: An Industry-Level Investigation. Review of World Economics, 145(4), 689-712.

5. Bilgili, F., Halici-Tuluce, N., Dogan, I. (2012). The Determinants of FDI in Turkey: A Markov Regime-Switching Approach. Economic Modelling, 29, 1161-1169.

6. Borensztein, E., De Gregorio, J., Lee, J.-W. (1998). How Does Foreign Direct Investment Affect Economic Growth? Journal of International Economics, 45(1), 115-135.

7. Bosworth, B., Collins, S. M. (1999). Capital Flows to Developing Economies: Implications for Saving and Investment. Brookings Papers on Economic Activity, 30(1), 143-180.

8. Brooks, C. (2014). Introductory Econometrics for Finance. Cambridge: Cambridge University Press.

9. Cardoso, E., Dornbusch, R. (1989). Foreign Private Capital Flows. In H. Chenery \& T. N. Srinivasan (Eds.), Handbook of Development Economics 1st ed., Vol. 2 (pp. 1387-1439). North Holland: Elsevier.

10. De Mello, L. (1999). Foreign Direct Investment-Led Growth: Evidence from Time Series and Panel Data. Oxford Economic Papers, 51(1), 133-51.

11. Desai, M. A., Foley, C. F., Hines Jr., J. R. (2005). Foreign Direct Investment and the Domestic Capital Stock. The American Economic Review, 92(2), 33-38.

12. Feldstein, M. (1994). The Effects of Outbound Foreign Direct Investment on the Domestic Capital Stock. In NBER Working Paper Series. National Bureau of Economic Research: University of Chicago Press.

13. Fry, M. (1993). Foreign Direct Investment in a Macroeconomic Framework: Finance, Efficiency, Incentives, and Distortions. Policy Research Working Paper Series, 1141.

14. Hejazi, W., Pauly, P. (2003). Motivations for FDI and Domestic Capital Formation. Journal of International Business Studies, 34(3), 282-289.

15. Jirasavetakul, L.-B., Rahman, J. (2018). Foreign Direct Investment in New Member State of the EU and Western Balkans: Taking Stock and Assessing Prospects. In IMF Working Paper Series, 18/187.

16. Kim, D. D.-K., Seo, J.-S. (2003). Does FDI Inflow Crowd Out Domestic Investment in Korea? Journal of Economic Studies, 30(6), 605-622. 
17. Kogut, B., Singh, H. (1988). The Effect of National Culture on the Choice of Entry Mode. Journal of International Business Studies, 19(3), 411-432.

18. Kumar, N., Pradhan, J. P. (2002). Foreign Direct Investment, Externalities and Economic Growth in Developing Countries: Some Empirical Exploration and Implication for WTO Negotiations on Investment. RIS Discussion Paper, 27/2002.

19. Markusen, J., Venables, A. (1999). Foreign Direct Investment as a Catalyst for Industrial Development. European Economic Review, 43(2), 335-356.

20. Sauramo, P. (2008). Does Outward Foreign Direct Investment Reduce Domestic Investment? Macro-Evidence from Finland. Helsinki: Labour Institute for Economic Research. 